Short Communication

\title{
Electrochemical Corrosion and Mechanical Properties of Two Biomedical Titanium Alloys
}

\author{
Chien-Lung Huang, Tao-Hsing Chen *, Chia-Chin Chiang and Shih-You Lin \\ Department of Mechanical Engineering, National Kaohsiung University of Applied Sciences, \\ Kaohsiung 807, Taiwan \\ *E-mail: thchen@kuas.edu.tw
}

doi: $10.20964 / 2018.03 .26$

Received: 15 September 2017 / Accepted: 2 January 2018 / Published: 5 February 2018

The electrochemical corrosion and mechanical properties of two biomedical titanium alloys (Ti-13Nb$13 \mathrm{Zr}$ and $\mathrm{Ti}-15 \mathrm{Mo}$ ) are investigated by means of electrochemical impedance spectroscopy (EIS) and a material testing system (MTS). The EIS results obtained in aerated Ringer's solution show that Ti$13 \mathrm{Nb}-13 \mathrm{Zr}$ has a higher corrosion resistance than Ti-15Mo. Consequently, of the two alloys, Ti-13Nb$13 \mathrm{Zr}$ has superior biocompatibility. Furthermore, the Quasi-static testing results reveal that $\mathrm{Ti}-13 \mathrm{Nb}-$ $13 \mathrm{Zr}$ also has superior mechanical properties at strain rates in the range of $10^{-3} \sim 10^{-1} \mathrm{~s}^{-1}$.

Keywords: electrochemical, corrosion, Ti-13Nb-13Zr alloy, Ti-15Mo alloy, mechanical properties, strain rate.

\section{$\underline{\text { FULL TEXT }}$}

(C) 2018 The Authors. Published by ESG (www.electrochemsci.org). This article is an open access article distributed under the terms and conditions of the Creative Commons Attribution license (http://creativecommons.org/licenses/by/4.0/). 